\title{
MOVEMENTS OF WAGES OVER THE BUSINESS CYCLE: AN INTRA-FIRM VIEW
}

\author{
Beth Anne Wilson \\ Federal Reserve Board
}

December 20, 1996

\begin{abstract}
This paper tests the hypothesis that fins' adjust to the business cycle by altering employment through promotion and hiring and hold the s@ structure and salaries assigned to jobs relatively constant. Two comprehensive fro-level panel datasets are used to examine salary setting and worker movement within fins. The salary structure is found to be rigid while promotion rates are cyclically sensitive. In contrast to the hypothesis, wage cyclicality in these two firms is driven by changes in salaries associated with jobs rather than by worker movement. An additional finding is that salaries in the two firms are countercyclical.
\end{abstract}

I had very helpful discussions with Olivier Blanchard, Julio Rotemberg, George Baker, Stan Fischer, Robert Solow, and Stacey Tevlin. Marcello Estevão deserves special thanks for his advice. I am extremely grateful to George Baker, Bengt Holmström, and Michael Gibbs for allowing me to "borrow" the data for firm 2. I also wish to express my deep appreciation and gratitude to the people who assisted me in acquiring data for firm 1. This work was supported in part by the National Science Foundation and the Board of Governors of the Federal Reserve but the views presented are solely my own and do not necessarily represent those of the Federal Reserve Board or its staff. 


\section{INTRODUCTION}

Aggregate wages are mildly procyclical, industry wages are acyclical, and individual wages are more strongly procyclical. ${ }^{1}$ To explain this variation, Solon and Barsky (1989) propose the following hypothesis: the wage structures of firms within an industry remain relatively fixed throughout the business cycle; procyclical employment in high wage industries generates mildly procyclical aggregate wages; and procyclical opportunity to upgrade to better jobs across and within firms leads to individual wage procyclicality. They conclude that, "Further empirical and theoretical research in this area might be especially fruitful." (Solon and Barsky, 1989, p. 28)

Two aspects of this hypothesis have been particularly hard to test: the rigidity of firms' wage structures and the connection between intrafirm worker movement and wage cyclicality. ${ }^{2}$ In a paper on the response of wages to high unemployment, Bewley and Brainard (1993) remark,

The procyclic behavior of average wages of a panel of people seems to be accounted for by the fact that people move from lower to higher paying jobs in a boom and do the contrary in a recession. Such movements could make the average pay of a panel move up and down in sympathy with the economy even if pay levels for particular jobs did not move at all. Unfortunately, no studies of the cyclic behavior of pay for particular jobs seem to have been done.... (p. 12)

The connection between intrafirm worker movement and cyclicality of aggregate wages is not new. In the 1950s, John Dunlop and Melvin Reder argued that the inflexible nature of pay structures in many firms might inhibit wage movements and, thus, prevent labor markets from clearing. Doeringer and Piore (1971) formalize this idea in their theory of internal labor markets. Modifying these arguments, Reder (1955) and Hall (1974) present models where the wage structure is bureaucratically determined and unaltered over the business cycle, but hiring and promotion adjust to drive wages toward equilibrium. Hall explains, "Rigid scales can coexist with rapid changes in wages because workers change jobs frequently." (p. 345) In this framework, actual wages adjust to real and nominal shocks to the extent that workers are upgraded or downgraded within the wage structure. More

\footnotetext{
${ }^{1}$ See Blanchard and Fischer (1989), Chirinko (1980), Bils (1985), Shin (1994), and Solon, Barsky, and Parker (1994).
}

${ }^{2}$ The wage structure of the firm is generally considered to be a pay classification system that defines jobs as collections of tasks and then sets a wage range that workers in the job can be paid. 
recently, using the National Longitudinal Study of Youth (NLSY), Akerlof, Yellen, and Rose (1990) find evidence of sizable upgrading and downgrading of jobs when workers switch firms over the cycle.

If the study of wage cyclicality is to be complete, the importance of intrafirm movement and the impact of firm pay structures must be determined. However, standard aggregate and longitudinal datasets cannot truly test for the intrafirm movement of workers. Datasets which track individuals provide little information on the internal labor market. For example, the NLS does not record intrafirm job changes and the Panel Study of Income Dynamics (PSID) measures of tenure and job switching are very inaccurate, even for moves across firms. (Brown and Light, 1992) Even if the PSID data had no measurement error, it would still provide an incomplete picture since there would be very few, if any, observations from any one firm. Establishment level data that contain information on wage scales, job classification, raises, individual's characteristics, and pay are needed. But the current establishment datasets, such as the Census Bureau's Longitudinal Research Database, do not contain this information.

For now, the lack of data means that research must be done on a case by case basis. One of the only such studies, Solon, Whatley, and Stevens (1994), uses firm level data to test for wage cyclicality during the interwar years. In their estimates, wages appear to be procyclical, with wages of intra-firm movers more procyclical than stayers. However, none of the coefficients is statistically significant, the sample size is very small--for some years fewer than 10 movers and 40 total observations in a firm, and the firms' hierarchies are unknown.

In contrast to the earlier work, this paper uses larger, more contemporary, and more complete firm datasets to better examine the cyclical behavior of pay for particular jobs and to test the Reder-Hall hypothesis that job change within firms allows circumvention of rigid pay structures. Panel datasets with information on individuals' wages, job, age, sex, and tenure from two service-producing firms in the private sector are used. The data for the first firm contains close to 22,000 worker-year observations and detailed information on the firm's annual pay scales from 1982 to 1994. The dataset for the second firm spans 1969 to 1988, has about 60,000 worker-year observations, and includes additional information on the race, education, and performance evaluations of the workers as well as firm data on annual profits. 
The results using this data support the view that the wage structure, as defined by the firm, is insensitive to the business cycle. Turnover and promotion respond somewhat to labor market variables, providing some indication that the rigid pay scales are circumvented. However, contrary to theories propounding the importance of job switching, wage cyclicality is driven by the wages of workers who remain in the same job and not by job switching. A particularly interesting result is that real wages are countercyclical, a finding that contradicts previous research using the NLS and PSID databases.

The structure of the paper is as follows: after the introduction, section two describes and summarizes the datasets; section three presents the results; a discussion of robustness tests and specification issues are found in section four; and section five concludes.

\section{THE DATA}

This section provides a brief overview of the two datasets used in the paper, highlighting three aspects of the data that are most relevant for this paper: the pay structures, the flow of workers through the structure, and the movement of workers' wages. The data from each firm are discussed separately and then the main characteristics of the datasets are summarized and compared.

\section{A. Firm 1}

Firm 1 is large -- between 7,000 and 8,000 employees, non-profit. private-sector, and serviceproducing. Establishments providing its particular service employ close to 8 percent of the U.S. urban labor force. The dataset for this firm contains observations for its support staff -about 1,700 workers per year from 1982 to 1994. In total there are about 22,000 observations on approximately 6,000 workers. The variables are salary, hours/week, job code -- including level and job title ${ }^{3}$, tenure, age, sex, and an identification number for each support staff employee as of January 1 of each year.

The pay structure of the support staff workers is fairly standard for large firms and it is important to note that, unlike in many models, here there is not a one-to-one relationship

${ }^{3}$ Jobs are assigned a 5-digit classification code; the first two digits are the grade level, the last three are the job code. Job codes are constant across levels, for example, a secretary in level 1 has code GA018 and in level 4 has code GD018. 
between jobs and wages. Jobs are classified into four levels breed on the skill, training, experience, and education required to perform the tasks of the job. Within each level are numerous job titles. ${ }^{4}$ The salaries for all the jobs in a given pay grade are restricted to fall within the minimum and maximum salaries that define each level's salary range or pay grade. Level four is the highest and level one is the lowest. Support staff employees are given a salary in their level depending on the job, their skill and experience, the salaries of their coworkers, and labor market conditions. The ranges for this firm are fixed annually, from April to April. For each classification level, the dataset contains the annual 35-hour, full-timeequivalent salary range. Graph 1 plots the real range maximum and minimum for each level over time. The scale on all four graphs is the same, making it easy to see that pay levels overlap considerably. The overlap provides some indication that pay grades delineate responsibilities and are not merely convenient ways to differentiate salaries.

To change the salaries of the workers, the firm gives each department a percentage increase in its support staff budget, or raise allotment. In percentage terms, the allotment is identical across departments and can only be distributed as raises. Benefits are constant across levels, so salary growth within levels is determined solely by raises, with all levels subject to the same distribution of raises. Raises are based on merit and are limited by the total annual department budget. The difference between the lowest and highest raise is small, typically one to three percent.

Because the focus of this study is on the significance of intrafirm movement, it is important to classify and examine the amount of such movement. For this section, in a given year, workers are labeled as "stayers" if they did not switch jobs or pay grades, did not enter the firm in that year, and will not leave the firm in the following year. Workers are classified as "movers" in a given year if they switched pay grades. These two classifications are mutually exclusive. Workers who flow in and out of the firm are classified as "beginners" and "leavers", categories that are not mutually exclusive. More specifically, in a given year, workers are classified as beginners/leavers if that year represents their first/last full year of work. Graph 1 also shows the average wage of those in the various movement classifications

${ }^{4}$ Examples of jobs in each level are as follows: level 1-- junior computer operator and clerical assistant; level 2-assistant computer operator, office assistant; level 3-- computer operator, senior office assistant; level 4-- senior computer operator, administrative resistant. 
by grade while graphs 2 and 3 present the distribution of workers across grade and movement type. Over the period, the number of total support staff fluctuated between 1630 and 1730 workers, as can be seen in the top panel of graph 2. The middle panel of graph 2 and graph 3 highlight that movement in the internal labor market is relatively high during the mid-80's but low at the beginning and end of the sample. The average probability of moving in a particular year is 11 percent. Over the period, about 1900 workers changed level, 93 percent to a higher grade, and the distribution of workers among the grades varied across the period as the fraction of workers in grades 2 and 3 declined steadily over the period while the proportion of workers in grades 1 and 4 grew, as can be seen in the final panel of graph 2 .

The majority of the 15,600 observations of salary growth has positive nominal (97\%) and real salary growth $(76 \%)$ over the period. ${ }^{5}$ Growth rates are calculated by taking the change in the log average annual salary in each year for each category and then averaging these changes across time. In almost no cases did nominal salaries fall, while about 25 percent of all observations of real salary growth are negative. There are very few incidence of zero nominal or real growth. Table 1 shows that the across-time average real salary growth for all workers is 1.3 percent, but salary changes vary considerably across worker groups. For stayers, the workers who are stable across the year, real salary growth is lower and less volatile than the total. Average real salary growth is highest for workers who leave or join the firm. Real salary growth for movers is low. ${ }^{6}$

${ }^{5}$ Nominal salaries and salary ranges were converted to real terms using the CPI for the firm's metropolitan area. The base year is 1982-84 $=100$. Since salaries and ranges are changed each year in April, the CPI used was the April to March 12-month average. The salary ranges and salary measures have been standardized to a 35-hour work-week.

${ }^{6}$ Part of the reason for low salary growth for movers is that both promotions and demotions are included in the definition of movers. If only promotions are considered, the annualized average salary of movers grew 0.63 percent over the period. Another explanation for low salary growth of movers is that here the growth rate represents the change in average salary for movers from one year to the next. If workers are moving from an increasingly lower part of the salary distribution this would account for the slow growth. 
Table 1- Growth of Annual Average Real Salaries by Category (Firm 1 and 2)

\begin{tabular}{||l||c|c|c|c|c||}
\hline \hline & Total & Stayers & Movers & Beginners & Leavers \\
\hline \hline Firm 1 & & & & & \\
Mean & 1.32 & 1.22 & 0.44 & 1.13 & 1.36 \\
Std. Error & 1.67 & 1.52 & 2.32 & 2.00 & 2.65 \\
\hline Firm 2 & & & & & \\
Mean & -0.06 & -0.06 & -0.22 & 0.65 & -0.28 \\
Std. Error & 3.65 & 3.87 & 5.59 & 6.38 & 5.47 \\
\hline \hline
\end{tabular}

Note: Growth rates were calculäted by generating the average salary level for the various ciassific $\left.\right|_{10 n}$ categories for each year and then calculating the change in logs-for each year. Stayers are those who neither moved, began, or left during a given year, movers are those who moved during a given year, and beginners and leavers are those who moved in or out of the firm the year prior or following the current one, respectively.

\section{B. Firm 2}

The information for firm 2 comes from the personnel records of management workers in a large, for-profit, service-sector firm. The dataset was compiled by George Baker, Michael Gibbs, and Bengt Holmström (BGH) and is detailed in BGH (1993, 1994a, and 1994b). As of December 31 of each year from 1969-1988, observations exist on the following variables: employee id., age, sex, race, education, performance ranking, salary, job level, and a dummy for title switch. ${ }^{7}$ In total there are about 62,000 person/year observations for about 12,000 individuals. The management staff comprises roughly 20 percent of the firm's total workforce over the time period. A small percentage of the sample is excluded because salaries are denominated in foreign currency. Finally, financial information on the firm's return on resets and normalized assets and net income are also included.

Unlike the dataset for the first firm, this firm's structure is not known explicitly -- i.e. this dataset does not contain the official pay compensation matrix, pay range, and raise allocation figures. To circumvent this problem, BGH have generated a hierarchy using the transition matrix across job titles. To assign jobs to levels they begin with 14 major titles -about 93 percent of those workers with coded titles (90 percent of all observations). Titles

${ }^{7}$ Unlike firm 1, for firm 2 the date the worker enters the firm is not available. Therefore, a tenure is known only for employees who entered the firm after 1969. Because firm employment grew strongly over the period, this restriction eliminates fewer than 20 percent of the sample, leaving over 48,000 worker/year observations. 
assigned to level 1, the lowest level in the hierarchy, are selected based on hiring patterns. Almost all workers holding these titles are hired in rather than transferred from other positions. ${ }^{8}$ To determine titles in other levels, the salary matrix plays a larger role. Titles which represented the primary source of shifts from level 1 are assigned to level 2 and so on. The assignment of titles to levels is fairly straightforward and a diagram of the hierarchy is presented in the first graph in BGH (1994a). The hierarchy allows measures of promotion and job switching to be identified, but it is impossible to determine whether the firm's official salary policy, as represented by the salary ranges and raise allocations, matches the movement of individual workers' salaries.

The number of management employees in firm 2 more than quadrupled during the 20 year sample period to over 5,000 by 1988 . Turnover increased across the period as hires as a percentage of the workforce rose from 16 to 19 and the percentage of leavers grew from 10 to 15 percent. On average 18 percent of the firm's workforce switched jobs, but each year the percentage who switched jobs ranged from 14 percent in 1988 to 24 percent in 1982 . (See graph 4.) Graph 5 shows the shifts in movers, leavers, and stayers. Unlike firm 1, there appear to be no trends: the fraction of the workforce in each grade level remains stable as the firm grew.

Also unlike firm 1, the average annual real salary of workers in firm 2 did not grow at all between 1969 and 1988. (See graph 5 and table 1.) This lack of growth is not a function of changes in the composition of the workforce across pay levels but remained true for workers across movement categories and grades. While the average real salary shows no growth over the 20-year period, it fluctuates significantly from year to year. Across worker categories, stayers' salaries saw no growth and the lowest variance. The salary for new hires varied the most and rose slightly over the period. Salaries for movers fell over the sample, as did the average salary for movers in firm 1.

As for individual salary growth, 93 percent of the observations have positive nominal salary growth and the remaining 7 percent are almost all cases of zero nominal salary change. The nominal salary fell for only 25 observations. In real terms, 22 percent of the observations

\footnotetext{
${ }^{8}$ Because only managerial staff are observed it is possible that workers labeled as hires were actually transferred from other areas of the firm such as clerical staff. BGH suppose that such transfers are probably infrequent and those transferred are treated similarly to new hires.
} 
of salary growth are negative; the rest are positive. The distribution of real and nominal salaries is similar to that of firm 1 .

\section{Summary}

Figure 1 and table 2 summarize the datasets and describe the variables used in this study. Although the datasets are very similar, there are interesting contrasts. The time periods spanned by the two datasets differ. Data for firm 1 are from 1982-1994, giving a picture of the latest recession and recovery. Data from firm 2 span 1969 to 1988, close to the periods covered by the NLS and PSID datasets. Results using aggregate data are known to be sensitive to time period so it is possible that variations in the responses of the two firms can be attributed to the sample period. (Sumner and Silver, 1989)

There are other distinctions as well that may prove relevant when comparing the results. The firms are from separate industries: the industry of firm 2 is more cyclically sensitive than that of firm 1. In addition, firm 1 is non-profit while firm 2 is for profit. Workers in firm 1 come from a local labor market while firm 2 workers are drawn from a national labor market. Occupations of the workers in the panel also differ across firms. Data from firm 1 are for support staff workers who are probably more cyclically responsive than managers, more affected by local rather than national labor market conditions, and less sensitive to internal firm factors. Firm 2 examines management workers whose movements and salaries may be more sensitive to national labor market conditions and firm profit. Firm 1 alone has official measures of the salary matrix and raises allocations, so only for this firm

can the cyclical sensitivity of the salary structure be tested. However, just firm 2 has education and performance measures as additional controls for worker quality. 
Figure 1- Summary of Datasets

Firm 1

-Non-Profit

-Support Staff Workers

.1/1/82 to $1 / 1 / 94$

- Variables in panel:

id., salary, job code,

pay grade, age, sex,

year began at the firm

-Add'l variables:

pay structure across time, raise allocations, method for classifying workers

- One geographical location
Firm 2

- For Profit

-Managerial Workers

- $12 / 31 / 69$ to $12 / 31 / 88$

-Variables in panel:

id., salary, pay grade,

job switch, age, sex, race, education, and performance evaluation

- Add'l variables:

return on resets, normalized net income and assets

-Multiple geographical locations

Table 2- Summary Statistics for Both Firms*

\begin{tabular}{||l|rrrr||}
\hline \hline & \multicolumn{2}{|c}{ Firm 1 } & \multicolumn{3}{c||}{ Firm 2 } \\
Variable & Mean & Std.Dev. & Mean & Std.Dev. \\
\hline Real Salary (\$85) & 15,731 & 2,750 & $\mathbf{4 9 , 4 3 7}$ & $\mathbf{4 , 5 0 3}$ \\
Real Sal Growth (\%) & 1.3 & 1.7 & -0.1 & $\mathbf{3 . 7}$ \\
Age (Years) & 38 & 12 & $\mathbf{4 0}$ & $\mathbf{1 0}$ \\
Sex (F=1,M=2) & 1.17 & 0.37 & -- & - \\
Education (Years) & -- & -- & 15.4 & 2.5 \\
Performance(Scale=1-4) & -- & -- & 1.89 & 0.72 \\
Move (Y=1,N=0) & 0.11 & 0.31 & 0.18 & 0.39 \\
Grade (1-4 \& 1-7) & 3.21 & 0.72 & 2.42 & 1.15 \\
Tenure (Years) & 6.78 & 7.12 & 4.47 & 3.58 \\
No. of Obs (Total) & 21,632 & -- & 59,773 & - \\
\hline For observations where salary exists.
\end{tabular}

Note: Real salary figures are deflated by the CPI (1985=100). For firm 2, sex and race dummies exist but are not labeled at the request of the firm. Performances are ranked from 4 to 1 with 1 being the highest. Grades for firm 1 progress from 1 to 4 and for firm 2 from 1 to 7 . Tenure calculations for firm 2 begin with entrants in 1970. 


\section{RESULTS}

As discussed earlier, the proposed explanation for the divergent estimates of salary cyclicality at the aggregate, industry. and individual level is that rigid pay structures keep the salaries of jobs constant over the business cycle while variations in hiring and promotion rates lead to procyclical salaries for workers. This section tests the hypothesis by first analyzing the wage structure of the firm and testing for its rigidity, and then examining the movement of the workers and their salaries within this structure.

\section{A. Analysis of the firm's salary structure.}

Given the organization of the support staff, the firm has two measures of the pay structure: raise allotments and salary ranges. Recall that raise allotments are annual percentage increases the firm gives each department to augment its salary budget. Salary ranges are the maximum and minimum salary levels which define each pay grade. These variables exist only for firm 1. Without taking a stand on which measure better reflects the firm's wage structure, this section examines the two components for rigidity, first by a cursory visual look at the pay structure, followed by regression tests of its sensitivity to the business cycle, and finally by an examination of the distribution of salaries within the structure over time.

\section{Graphical view}

As was shown earlier, graph 1 plots the real salary range for each pay level from 1982 to 1994. ${ }^{9}$ The entire compensation structure moves over time but there is no change in the relative positions of the grades: Within each level and for each year, the difference between the level's maximum and minimum (i.e. the salary range) is 50 percent of the minimum allowable salary for that level. Across levels, the minimum of each level is 14 percent greater than the minimum of the level below it. Because the upper and lower bounds of each level are defined in strict relation to each other, the pay structure is internally rigid and the firm can adjust the compensation structure by choosing a single growth rate. On average over the period there was no growth in the real ranges but, from year to year, real range growth fluctuated between 2.8 and -3.8 percent.

${ }^{9}$ Since data are measured on January 1 st of each year, the salary ranges and raises which apply to the observations are those from the previous year. 
The other measure of the firm's salary structure is the real salary allotment. Over the period the increase in the real salary budget given to each division averages one percent per year. However, the real allotments vary over time, ranging from 3.8 to -1.4 percent. Despite the differences in average growth rates, the raise allocations and ranges are fairly similar, suggesting that the two elements of the wage structure are in accordance with each other.

Graph 6 plots the average real growth rate of the salary range and raises. As can be seen, they are closely, but not exactly related--the correlation between the two being 0.8 . Graph 6 also shows that the annual real adjustments are fairly variable. (In nominal terms, this is not the case. Nominal raise and range adjustments are generally $s$ able and sometimes equal for several years. For example, between 1982 and 1985 the range grew 5 percent each year in nominal terms.)

\section{Regression analysis}

It can be seen that the wage structure is not completely rigid but how much of the structure's fluctuations is linked to labor market fluctuations? Table 3 presents estimates of cyclical sensitivity for real raise allocations and salary ranges of firm 1. Independent variables are metropolitan employment growth, the inflation rate, a trend, and a constant. In studies of wage cyclicality, it is standard to use the unemployment rate as the cyclical variable but metropolitan unemployment rates are measured with a large degree of error so employment rates are used. ${ }^{10}$ These too may suffer from measurement error and, to be on the safe side, changes in metropolitan employment are instrumented with national employment growth. ${ }^{11}$ Since raises in firm 1 go into effect in April of each year, employment growth is calculated using the annual average of monthly data from April to March. In addition to local unemployment rates, the local consumer price index is used as a measure of business cycle conditions and instrumented for in a similar fashion.

\footnotetext{
${ }^{10}$ See National Commission on Employment and Unemployment Statistics, Counting the Labor Force, 1979 for a discussion of measurement problems of state and local employment data.

${ }^{11}$ The Rbar $^{2}$ from the first stage is .54 for a regression of metropolitan employment on the other independent variables.
} 
Tahle 3 -- Cyclical Sensitivity _of Pay Structure (Eirm..1_)

\begin{tabular}{||l||c|c||}
\hline \hline Variable & Real Raise Allocation & Real Range Growth \\
\hline \hline$\Delta$ Ln(Employment) & -0.112 & 0.138 \\
(std. error) & $(0.106)$ & $(0.092)$ \\
Inflation & -0.526 & -1.000 \\
(std. error) & $(0.169)$ & $(0.147)$ \\
Number of Obs. & 13 & 13 \\
\hline \hline
\end{tabular}

Note: The dependent variabie, eltíer real 'rinse' allócation or real range growtin' Is regressed on the change in log metropolitan employment, the change in $\log$ metropolitan CPI, a trend-, and a constant. Change in log of national employment and CPI figures are used as instruments.

Table 3 details the results of the regression of salary ranges and raises on local business cycle variables. The response of both raise allocation and range growth to employment growth is not significantly different from zero, implying little influence of the external labor market conditions on the pay structure. The variables are more sensitive to the inflation rate. $^{12}$ An increase in the inflation rate decreases the growth of the real salary ranges suggesting some nominal rigidity. The results are insensitive to the inclusion of lags of employment and inflation or the use of the unemployment rate as an explanatory variable.

Does the salary structure's lack of cyclical sensitivity affect workers' salaries. Graph 1 also presents the average salaries for workers classified as stayers, hires or beginners, and leavers for each level. These wage averages are concentrated at the lower end of the range. Perhaps because of the room for salary growth at the top of each range, wage ranges are almost completely binding, with only a few observations outside the range levels in any given year. Graph 7 takes a closer look at the distribution of salaries within grades for 1988. As was seen in graph 1 , the median salary is generally below the middle of the pay range. The salary distribution shifts up in the range as the grade levels advance.

If the salary structure is binding, one effect could be the bunching of workers at the top of the range or the shifting up of the salary distribution within grade levels in times of tight labor markets. One measure of the shape of the distribution is skewness. Graph 8 plots the skewness coefficient for each grade over time. If salaries are evenly distributed over the

\footnotetext{
12 The effect of the inflation rate on the salary structure and salaries is the focus of "Inflation and Pay: An intra-firm view," Beth Anne Wilson, 1996, mimeo.
} 
range then the skewness coefficient will be zero. In the beginning of the sample period, the distribution of salaries is highly positively skewed, with the great mass of salaries at the bottom of the range. Over time the distribution became much more symmetric.

Table 4 tests the cyclical sensitivity of this skewness in the same way that the cyclicality of the range structure was tested in table 3 . For grades 2,3 , and 4 , which contain the majority of the workers, the skewness of the salaries falls in response to greater employment growth. In this case, the mass of salaries moves closer to the center of the wage range, thus providing one additional indication that the salary structure is more rigid than the salaries themselves.

In sum, the two main elements of the salary structure of firm 1 are relatively insensitive to business cycle variations in the labor market while the distribution of salaries within each pay grade moves closer to the top of the range in response to positive movements in employment growth. While the results in table 3, provide some empirical confirmation of the institutional view that pay structures are inflexible over the cycle, the rigidity may be irrelevant given the large range of each level and the possibility of promotion for the workers. The next step is to look for greater evidence of rigidity in the wage structure by testing the sensitivity of turnover and promotion rates to business cycle variables.

Table 4 -- Cyclical Sensitivity of Distribution of Wages with Grades as Measured by Skewnes: Firm 1)

\begin{tabular}{|c|c|c|c|c|}
\hline \multirow{2}{*}{ Variable } & \multicolumn{4}{|c|}{ Skewness of Real Wage Distribution w/in Grade } \\
\hline & Grade 1 & Grade 2 & Grade 3 & Grade 4 \\
\hline$\Delta \operatorname{Ln}($ Employment $)$ & 0.037 & -0.114 & -0.124 & -0.103 \\
\hline (std. error) & $(0.064)$ & $(0.070)$ & $(0.084)$ & 0.056 \\
\hline Inflation & 0.104 & 0.178 & 0.136 & 0.067 \\
\hline (std. error) & $(0.106)$ & $(0.117)$ & $(0.140)$ & $(0.093)$ \\
\hline Number of Obs. & 13 & 13 & 13 & 13 \\
\hline
\end{tabular}




\section{B. Analysis of worker and salary movement}

The importance of worker movement over the cycle for the behavior of firm wages is first examined through a simple variance decomposition. This analysis is followed by a more detailed examination using regressions and instrumental variables to control for variance in worker characteristics over the cycle.

\section{Variance Decomposition}

As a preliminary examination of the influence of worker movement on overall firm wage cyclicality, this section presents the results of decomposing the variance of firm salary growth over the period into that variance due to the wages of movers in a given period and the wages of stayers. Equation (1) illustrates the exercise:

TOTAL VARIANCE = WITHIN-GROUP VARIANCE + BETWEEN-GROUP VARIANCE

(1) $\operatorname{VAR}\left(\Delta s_{T t}\right)=\operatorname{Pm} \operatorname{VAR}\left(\Delta_{m t l}\right)+(1-P m) \operatorname{VAR}\left(\Delta s_{s t l}\right)+\underset{m m}{P}\left(s-s_{T}\right)^{2}+(\sim-p m)\left(s_{s}-s_{T}\right)^{2}$

Here, $\operatorname{VAR}\left(\Delta \mathrm{s}_{\mathrm{Tti}}\right)$ is the variance of real salary growth of all worker-year observations, with workers indexed by $i$ and years by $\operatorname{t.} \operatorname{VAR}\left(\Delta \mathrm{s}_{\mathrm{mti}}\right)$ is the variance in real salary growth of all worker-year observations where the worker is classified as a movers. Finally, $\operatorname{VAR}\left(\Delta \mathrm{s}_{\mathrm{st}}\right)$ is the variance in real salary growth of individual-year observations where the worker does not move. $\mathrm{P}$ is the proportion of movers in the sample of each firm. The average salary of all movers across time is $s_{m}$, while the average salary of all stayer across time is $s_{s}$ and the across-time average of all workers is $s_{\mathrm{T}}$. The first two terms of the equation represent the within-group variance and the second two terms represent the between-group variance.

Table 5 presents the decomposition results for firms 1 and 2. What is immediately striking is that the percent of total salary variance due to salary increases received when switching pay grades accounts for a relatively small percent of the total variance. For firm 1, movers, about one-tenth of all observations, account for a little under 30 percent of the firm's wage variance. For firm 2, the movers, comprising about 20 percent of the sample, account for 20 percent of the wage variance. A far larger amount of the variance in total salaries is accounted for by variance in the salary growth of stayers. Between-group variance accounts for about a third of the variance of firm 1 and tenth of the variance of firm 2 . 
Table 5- Growth of Annual Average Real Salaries by Category (Firm 1 and 2)

\begin{tabular}{|c|c|c|c|}
\hline & \multicolumn{3}{|c|}{$\%$ of total variance accounted for by... } \\
\hline & $\mathrm{P}_{\mathrm{m}} \operatorname{VAR}\left(\Delta \mathrm{s}_{\mathrm{mi}}\right)$ & $\left(1-P_{m}\right) \operatorname{VAR}\left(\Delta s_{s t i}\right)$ & Between Group Var. \\
\hline \multicolumn{4}{|l|}{ Firm 1} \\
\hline Total period & 26.9 & 40.5 & 32.6 \\
\hline High demand* & 26.8 & 42.3 & 30.9 \\
\hline Low demand & 27.2 & 37.3 & 35.5 \\
\hline \multicolumn{4}{|l|}{ Firm 2} \\
\hline Total period & 20.2 & 70.7 & 9.1 \\
\hline High demand** & 20.0 & 71.3 & 8.7 \\
\hline Low demand & 20.6 & 69.2 & 10.2 \\
\hline
\end{tabular}

How cyclically sensitive is this decomposition? The results change very slightly if the decomposition is taken over different subsets of the data. In periods of high demand, defined for firm 1 as times when the local unemployment rate is below 5.5 percent, a slightly but not significantly smaller share of total wage variance is due to the wage growth of movers. The same is true for firm 2, where high demand is defined as periods where the aggregate growth rate is above 1.3 percent. One explanation for this is that in periods of low demand only those workers who move receive any significant wage changes. However, judging from this table alone, the even in periods of low demand, the wage movement of movers does not appear large enough to drive the aggregate wage movements.

While this initial table casts doubt on the importance of grade switching in driving aggregate wage changes for the firms, there are several problems with this simple test. First, it resumes that the probability of moving is constant over time. If the probability of switching pay grades is highly sensitive to business cycle movements it might be possible that this decomposition underestimates the importance of movers' wage growth. In addition, controlling for individual characteristics, such as age, tenure, education, and other skill 
variables, may reveal a far more cyclically sensitive wage for movers. Finally, capturing the cycle only by a crude split of the data may not truly reflect cyclical changes in wage and worker movements. The next section addresses these concerns.

\section{Regression analysis}

How is the cyclicality of the aggregate firm salary influenced by intra-firm worker movement? In the first set of results, the pay structure of firm 1 was found to be fairly rigid. This rigidity could limit the cyclical sensitivity of real salaries. If Reder and Hall are correct, however, even if the structure binds, individual salaries will still react to the external labor market due to increased turnover and promotion. The variance decomposition results showed that even within wage ranges there was significant variance in salary growth. The current section tests for the effects of labor market variables and firm movement on salaries more explicitly.

As was shown in Solon, Whatley, and Stevens (1994), a simple decomposition of the individual's expected salary growth helps highlight these issues. To capture the fact that workers switch jobs, let $\mathrm{P}=$ probability that a worker changes jobs within the firm, $\mathrm{s}_{\mathrm{m}}=$ logarithm real salary if a mover. and $\mathrm{s}_{\mathrm{s}}=$ logarithm real salary if a stayer. Here, the classification of stayers includes hires and leavers who did not switch grades. Then

$$
\text { (2) } E(\Delta s)=(1-P) E(\Delta s)_{s}+P E(\Delta s)_{m}=E(\Delta s)+P E\left(\Delta s_{m}-\Delta s\right)
$$

(3) $\delta E(\Delta s) / \delta(\Delta c)=\delta\left(E \Delta_{s}\right) / \delta(\Delta c)+P\left[\delta E\left(\Delta_{\mathrm{m}}-\Delta s_{j}\right) / \delta(\Delta c)\right]+E\left(\Delta_{\mathrm{m}}-\Delta s_{j} \delta P / \delta(\Delta c)\right.$

Equation (2) represents a worker's expected salary growth conditional on being in the firm. The second equation is the derivative of the top equation with respect to a cyclical variable. The left-hand side of equation (3) is the average cyclicality of the worker's expected salary. The first term on the right-hand side is within-job salary cyclicality, the second is cyclicality of the increase in salary growth associated with job changing, and the third the cyclical sensitivity of job switching. If total salary cyclicality is being driven by worker movement, then the sum of the second and third terms on the right hand side must make up a major portion of total salary cyclicality. 


\section{a. Probability of moving}

To begin to examine the cyclical effects, equation (3) is estimated element by element. This section estimates $\delta \mathrm{P} / \delta \Delta \mathrm{c}$ : the effect of the cycle on the probability of moving within the firm. Results show that $\delta \mathrm{P} / \delta \Delta \mathrm{c}$ is positive for workers in firm 1 and zero for workers in firm 2.

\section{i. Firm 1}

For firm 1, table 6 presents the outcome of logit regressions testing the response of moving to the business cycle. The results show that worker flows are positively correlated with the business cycle. The probability of switching pay levels is significantly procyclical. For example, given the average increase in metropolitan employment growth of 1.5 percent, the probability of moving will rise 0.024 , or 2.4 percent. The results indicate, as predicted, that intrafirm movement in this firm is consistent with the circumvention of a rigid salary schedule.

In addition to testing the cyclical sensitivity of the probability of moving and promotion, the cyclicality of employment growth in each movement category is estimated. The growth of firm employment is essentially acyclical in response to local employment growth. Breaking this result down, growth in the number of workers classified as stayers is not significantly cyclically sensitive while growth in the number of movers and hires is significantly procyclical. (See appendix A.)

Table 6 -- Cyclical Sensitivity of Probability of Intrafirm Movement (Firm 1)

\begin{tabular}{||l||c|c||}
\hline \multicolumn{1}{|c||}{ Independent Variables } & Prob of Moving & Prob of Promotion \\
\hline \hline$\Delta \ln ($ employment) & 0.016 & 0.014 \\
(std. error) & $(0.008)$ & $(0.007)$ \\
Inflation & 0.016 & 0.021 \\
& $(0.014)$ & $(0.013)$ \\
Number of Obs* & 11 & 11 \\
\hline
\end{tabular}

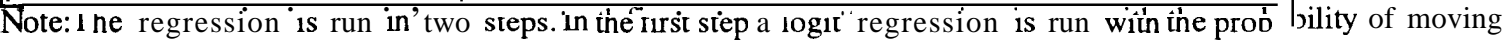
against individual characteristics and time dummies for each year. Next the coefficients of the time dummies are regressed on the log difference of local employment and prices, a trend, and a constant. (This process is outlined in more detail in the following section.) Finally, computed probabilities are estimated using the coefficients from the final regression and average changes in employment and prices.

* The number of observations in the first step of the regression is 14.500 . 


\section{ii. Firm 2}

For firm 2, table 7 contains results from logit regressions on the incidence of moving and promotion. Unlike firm l, regardless of the specification, these regressions show little sign of cyclicality. The probability of moving or promotion appears unaffected by the change in aggregate employment growth. Similar results, not shown here, hold if changes in log employment or real GDP are used.

Additional tests on the cyclical sensitivity of worker flows show total workforce employment and hires to be significantly countercyclical. The change in the number of employees classified as stayers is much less sensitive to the business cycle relative to the total. Across all categories, inflation appears to have little effect on the growth in employment.

For both firms, the results provide mixed evidence that employee movement responds to external market pressures. For firm 1, the total labor force is not cyclically sensitive but internal labor force movements are, providing some confirmation of the Reder/Hall theory that promotion rates adjust if the salary structure is rigid. For firm 2, the results are not as easily interpreted. Compared to firm 1, total firm employment is countercyclical, rather than procyclical, and intrafirm movement is unresponsive to the cycle. (Again see appendix A.)

Table 7-- Cyclical Sensitivity of Probability of Intrafirm Movement (Firm 2)

\begin{tabular}{||l||c|c||}
\hline \hline Independent Variable & Prob of Moving & Prob of Promotion \\
\hline \hline$\Delta$ Ln(Employment) & -0.006 & -0.008 \\
(std. error) & $(0.007)$ & $(0.008)$ \\
Inflation & 0.004 & 0.006 \\
& $(0.005)$ & $(0.006)$ \\
Number of Obs. & 17 & 17 \\
\hline
\end{tabular}

Note: Ihe regressión is run in two steps. in the' first stage a logit regression is run with the pro ability of moving against individual characteristics and time dummies for each year. Next the coefficients of the time dummies are regressed on the log difference of local employment and prices, a trend, and a constant. (This process is outlined in more detail in the following section. ) Finally, computed probabilities are estimated using the coefficients from the final regression and average changes in employment and prices.

* The number of observations in the first stage of the regression is 37,000 . 


\section{b. Real Wage Cyclicality}

To obtain the measures of salary cyclicality for the various categories of workers, the salary terms in the second decomposition, equation (3), are calculated. As in previous studies, a standard reduced-fore salary equation is used to estimate the various measures of $\delta \Delta \mathrm{s} / \delta \Delta \mathrm{c}$.

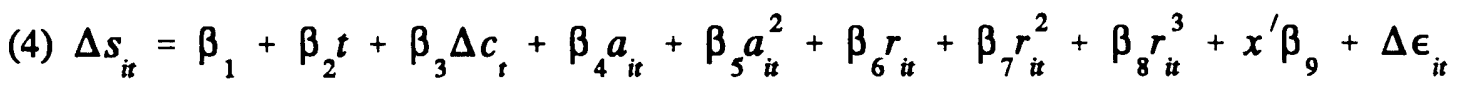

Equation (4) models the change log real salary as a function of a trend, $\mathbf{t}$; a variable $\mathbf{c}_{\mathbf{v}}$ capturing economic fluctuations; and polynomials in tenure, r, age, a, other personal characteristics such as sex and race, $x . \beta_{3}$ represents the sensitivity of salary growth to the business cycle.

Before estimating this equation the specification must be discussed. Because the equation is estimated in changes, individual specific effects and non-stationarities of the level of real salaries will not be concerns. However there is still the possibility that the error terms are cross-sectionally and serially correlated. If workers experience annual shocks that are not captured by the explanatory variables, the individual error terms will be correlated across workers. In addition, taking the first-difference could lead to serially-correlated errors if the errors in the salary level equation were white noise. These two problems will bias the standard-errors of the coefficients although the coefficients themselves will still be consistent.

To obtain the appropriate variance estimates for the cyclical coefficients, the regression is done in two steps. (Coleman, 1986)

\section{Step 1 OLS Regn: $\Delta \boldsymbol{s}_{i t}$ on $\boldsymbol{a}_{i t}, \boldsymbol{a}_{i t}^{\mathbf{2}}, \boldsymbol{r}_{i t}, \boldsymbol{r}_{i t}^{\mathbf{2}}, \boldsymbol{r}_{i t}^{\mathbf{3}}, x i$, year dummies \\ Step 2 OLS Regn: Estimated coefficients of year dummies on $t, \Delta c_{t}$}

In the first step, the change in real salaries is regressed on individual characteristics, year dummies, and a constant. Estimated year dummy coefficients from the first step represent average salary growth for each year, adjusted for age, tenure, and other personal characteristics. In the next step, the coefficients on the year dummies are regressed on the change in the cyclical variable, a time trend, and a constant. The coefficient on $\Delta \mathrm{c}$ from second regression will be an estimate of cyclical elasticity, $\beta_{3}$. Note that, had the regression 
been estimated in one step as is standard, the coefficients on employment and inflation would be unchanged, only the variance of the coefficients is affected.

The unconditional salary cyclicality of the individual worker, $\delta \Delta s / \delta \Delta \mathrm{c}$, is obtained by first estimating equation (4) for all workers and then using the coefficients on the year dummies as dependent variables in a regression on the cyclical variables yields. To generate estimates of $\delta \mathrm{E}\left[\Delta \mathrm{s}_{\mathrm{m}}-\Delta \mathrm{s}_{\mathrm{s}}\right] / \delta \Delta \mathrm{c}$--the incremental cyclicality of movers' salaries over stayers' salaries -- equation (4) is reestimated with interactive year dummies that are one when the worker switches jobs and zero otherwise. Using coefficients on the interactive dummies as the dependent variable in the second stage regression yields the incremental cyclicality of movers. The coefficients on the time dummies in this regression capture the cyclical sensitivity of the salary growth of stayers, $\delta \Delta s_{\S} \delta \Delta \mathrm{c}$.

\section{i. Firm 1}

Tables 8 (firm 1) and 9 (firm 2) display results from regressions using panel data to estimate the various measures of salary cyclicality. For firm 1, given that local labor market variables are measured with error, the national series for these variables are used as instruments.

For the total workforce, unconditional individual salaries are countercyclical when regressed on changes in the cyclical measure. For a one percentage point increase in local employment growth, firm salaries fall about 0.2 percentage points, a small fraction of the variance of these salaries. Breaking the results down by category, salaries for stayers -- the most stable of the workforce measures -- are more countercyclical and more significant than that of any other category. For movers, salaries are slightly less cyclical than stayers but that difference is not significant.

From the regressions, it appears that there are notable contrasts between the behavior of the pay structure and the workers in it, as well as distinctions in cyclical sensitivity across workers in different categories. The countercyclical response of the salaries of the total workforce is driven by the salaries for stayers. The salaries for movers are not more cyclically sensitive than those of stayers although they do resend more positively to inflation. 
Table 8-- Intrafirm Real Salary Cyclicality (Firm 1)

\begin{tabular}{||l||c|c|c||}
\hline \hline Independent Variables & $\begin{array}{l}\text { Total } \\
(\delta \Delta \mathrm{s} / \delta \Delta \mathrm{c})\end{array}$ & $\begin{array}{l}\text { Stayer } \\
\left(6 \Delta \mathrm{s}_{\mathrm{s}} / \delta \Delta \mathrm{c}\right)\end{array}$ & $\begin{array}{l}\text { Mover-Stayer } \\
\left(6 \mathrm{E}\left[\Delta \mathrm{s}_{\mathrm{m}}-\Delta \mathrm{s}_{\mathrm{s}}\right] / \delta \Delta \mathrm{c}\right)\end{array}$ \\
\hline$\Delta \ln ($ Employment) & -0.224 & -0.284 & 0.003 \\
(std. error) & $(0.133)$ & $(0.145)$ & $(0.097)$ \\
Inflation & -0.804 & -0.886 & 0.371 \\
(std. error) & $(0.251)$ & $(0.274)$ & $(0.183)$ \\
Number of Observations & 12 & 12 & 12 \\
\hline
\end{tabular}

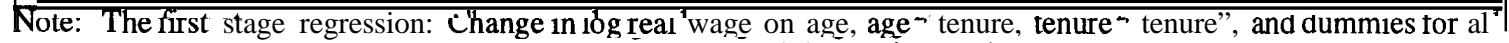
years with the regression for stavers and movers also containing an interactive time dummy which is the vear times 1 if the individual moved. Second stage regression: Coefficient on the time dummies on change in log metropolitan employment, change in log metropolitan CPI, trend, and a constant. The change in log employment and the CPI are instrumented with the national variables

The salary cyclicality coefficients estimated in these regressions, although very small in magnitude, are significantly negative, which is in contrast to recent findings in the literature. What could explain the difference? It is possible that characteristics specific to this firm are driving the salary response. It is non-profit, the workers are support staff, the time period is less procyclical, even in the aggregate. A comparison with firm 2 may shed light on these results.

\section{ii. Firm 2}

Table 9 includes the coefficients from the panel regressions of firm 2. Three cyclical measures are used: change in log employment, change in the unemployment rate, and change in real log GDP. The results are consistent across cyclical measures; therefore, only the results using employment growth are presented. Since the firm has offices across the country and data are for management workers, the national aggregates of these variables are used. For firm 2, the date when raises go into effect is not known, so the measures are annual aggregate CPI-U. In some versions of the regressions the firm's annual return on assets and normalized net income were used to measure firm performance. These variables were completely insignificant and so were not included in the final regressions. 
Table 9-- Intrafirm Salary Cyclicality (Firm 2)

\begin{tabular}{||l||c|c|c||}
\hline \hline Independent Variable & $\begin{array}{l}\text { Total } \\
(\delta \Delta \mathrm{w} / \delta \Delta \mathrm{c})\end{array}$ & $\begin{array}{l}\text { Stayers } \\
\left(\delta \Delta \mathrm{w}_{\mathrm{s}} \delta \Delta \mathrm{c}\right)\end{array}$ & $\begin{array}{l}\text { Movers-Stayers } \\
\left(6 \mathrm{E}\left[\Delta \mathrm{w}_{\mathrm{m}}-\Delta \mathrm{w}_{\mathrm{s}} \mathrm{s} / \delta \Delta \mathrm{c}\right)\right.\end{array}$ \\
\hline \hline$\Delta \operatorname{Ln}($ Employment) & -0.284 & -0.282 & -0.042 \\
(std. error) & $(0.288)$ & $(0.274)$ & $(0.161)$ \\
Inflation & -0.809 & -0.847 & 0.036 \\
& $(0.156)$ & $(0.148)$ & $(0.065)$ \\
$\mathrm{Rbar}^{2}$ & 0.62 & 0.67 & -0.19 \\
DW & 2.28 & 2.17 & 1.25 \\
Number of Obs. & 18 & 18 & 18 \\
\hline \hline
\end{tabular}

Note: The first stage regression: Change in log real wage on age, age ${ }^{2}$, tenure, tenure ${ }^{2}$, tenure', and dummies for all years with the regression for stayers and movers also containing an interactive time dummy which is the year times 1 if the individual moved. Second stage regression: coefficient on the time dummies on change in log employment, change in log CPI, trend, and a constant. The change in log employment and the CPI are instrumented with the national variables

For the initial specification, the year dummy coefficients are regressed on employment growth, a trend, and a constant. The coefficient on employment growth is countercyclical but insignificant. The inclusion of lags of unemployment lead to increasingly significant and negative coefficients. There is no evidence of significantly procyclical salaries in any category or any specification. Just as for firm 1, the effect of the business cycle on total individual salaries is driven not by worker movement or relative salary gains from moving but from the salaries of the stayers.

Surprisingly, both firms show countercyclical salaries and the reaction of salaries seems to be similar across worker categories in each firm. Salary cyclicality is largest for workers in the most stable category. Salary cyclicality for movers is not incrementally different from that of stayers. In so far as salaries and intrafirm movement are influenced by the external variables, there is not much evidence, in these results, of an internal labor market protecting the workers from outside labor market flcutuations. There appears to be little evidence here to support the fact that the salary cyclicality of the firm is driven by the movers. 


\section{ADDITIONAL ISSUES}

While the results clearly reject the importance of intrafirm movement in determining the response of the aggregate firm salary cyclicality, they also raise questions The finding of countercyclical salaries is at odds with earlier disaggregate studies. This section discusses the possibility of firm specific idiosyncrasies and considers additional explanations and tests for the robustness of the results.

\section{A. Possible firm or industry specific idiosyncrasies}

Given that this is a case study, it is always possible that the result of countercyclicality is simply due to firm or industry specific effects. This section explores the evidence to support such a view.

Firm 1 is from a non-profit industry in a sector whose salaries are not highly cyclically sensitive. Therefore, one may argue that its salary behavior differs from the aggregate. The industry effect should be mitigated, however, as the dataset tracks support staff workers. These workers probably have fewer industry or firm specific skills than managers. In addition. the firm participates in a salary survey with firms in the same metropolitan area and targets salary growth to the average or slightly above the average of the survey's participants. Since participants come from a variety of industries, many of them highly cyclically sensitive, support staff salaries are not linked solely to their industry's performance.

The optimal employment measure to capture local labor market conditions for firm 1 would be the employment of clerical workers in the industry and metropolitan area. Since this measure is unavailable, two other measures of employment are used to ascertain the cyclicality of industry/occupation employment relative to the business cycle. The first series is the employment of clerical workers in the metropolitan area. The second series is the employment of women in the industry of firm 1. The employment of clerical workers in the metropolitan area is highly positively correlated with state and aggregate employment. The employment of women in the firm's industry is very slightly positively correlated to state and aggregate employment. In either case, there is no indication that employment in the industry/occupation group is countercyclical. Unfortunately, salary data for this industry are 
not available.

For firm 2 there is even stronger evidence for procyclical industry behavior. Employment and salaries in the industry are procyclical.(Bils and McLaughlin, 1992) In addition, the firm's own profit measures are positively correlated with aggregate employment and GDP growth and negatively correlated with changes in the unemployment rate. In fact, in other respects, the firm's behavior is quite normal and Baker, Holmström, and Gibbs note no unusual characteristics of the firm and or its industry. It is certainly possible that either firm 1 or 2 have idiosyncratic qualities that would generate countercyclical salaries but after a cursory review of the evidence nothing is immediately apparent.

\section{B. Additional measures of firm salaries}

The salaries in both firms are more countercyclical for stayers than for any other worker classification. One explanation for this might be that there is adverse selection in the stayer category. Since the best workers are more likely to be promoted and promotion tends to be procyclical, stayers in bad times are of a higher quality than stayers in good times. While individual characteristics are controlled for to a certain extent, unobserved quality may play a role.

If this is a problem, a better measure to capture the salary associated with jobs is the average annual salary of all workers in each job classification. Accordingly, this average measure was built for 15 of the major job classifications of firm 1.13 Estimating the cyclicality of salaries in each of the 15 largest jobs separately with and without controlling for individual characteristics results in countercyclical salaries for all jobs and significant coefficients for 11 of the 15 cases.

Several other measures of the firms' salaries are constructed to gain a more complete picture of the cyclical response of salaries. First, all previous salary regressions have controlled for individual characteristics. Is it possible that looking at simple averages of salaries across all workers will yield a more acyclical or procyclical coefficient'? No, for both firms the aggregate salary is slightly more countercyclical than salaries controlling for individual characteristics and worker movement. The cyclicality of the aggregate measure

\footnotetext{
${ }^{13}$ The 15 major jobs are those having more than 1 percent of the total sample each. Combined they represent 84 percent of all worker/year observations.
} 
might also be driven by the changing proportion of workers in the various pay grades. However, building an aggregate salary series where the proportion of workers in the 15 major jobs for firm 1 is held fixed also yields significantly countercyclical salaries.

The purpose of this section has been to test the robustness of the countercyclical result across various specifications and salary measures. It has also been to examine any particular industry characteristics that could drive the result. No obvious industry characteristics seem to explain the negative relation between salaries and the business cycle in these firms. and the result is robust across various measures of salaries.

\section{CONCLUSION}

This paper began by stating the recent explanation for the divergent estimates of wage cyclicality at various levels of cyclicality. This standard hypothesis for why salaries of individuals are more cyclically sensitive than industry and aggregate salaries relies on the rigidity of the salary structure within the firms, coupled with cyclical promotion and turnover. This paper represents an initial test of this hypothesis.

There are four major results. First, the pay structure of firm 1 as measured by the growth in pay grades and raise allocations is inflexible to business cycle variables. The real pay structure does not adjust strongly to the rate of inflation and employment. The salary structure seems to be a long-term guide to the salary setting and worker organization rather than a flexible short-term mechanism for salary allocation.

Second, worker movement in firm 1 supports predictions of Reder and Hall that promotion rates adjust to counteract the rigidity of the pay structure. For firm 2, where the pay structure is not known, intrafirm movement is acyclical and total firm employment is countercyclical, despite procyclical firm profits.

Third, the cyclicality of the salaries of movers is not noticeably different from those who remain in the same job. This provides evidence refuting the theory that worker movement within the firm generates the observed wage cyclicality at the individual level. Neither cyclical promotion nor wages growth for movers is the driving factor behind the cyclical movement of wages in these two firms.

Fourth, empirical tests find salaries to be countercyclical over the business cycle. The 
result is robust to variations in specification for firms 1 and 2. This countercyclicality is not explained by obvious factors such as firm profit or industry demand.

While these results are only for two firms, interesting issues are raised. It appears that salaries for firm 1 are relatively independent of the firm's official pay structure. If this result holds more generally, efforts to restructure the pay system of firms must first establish the links between the pay structure and salary determination. These results also point to a surprising degree of flexibility in the salaries associated with workers and with jobs. The inflexibility of the pay structure does not translate into a rigidity of pay for jobs. 


\section{BIBLIOGRAPHY}

Abraham, KG and J.C. Haltiwanger, "Real Wages and the Business Cycle." Mimeo. March 1994

Akerlof, G. A., Yellen, J.L. and Rose, A.K. "Waiting for Work.” NBER Working Paper, No. 3385, 1990.

Baker, G., Gibbs, M., and B. Holmström, "Hierarchies and Compensation: A Case Study." International Economic Review, April 1993.

----, "The Internal Economics of the Firm: Evidence from Personnel Data." Quarterly Journal of Economics, December 1994a.

----, “The Wage Policy of a Firm.” Quarterly Journal of Economics, December 1994b.

Bewley, T. and W. Brainard. "A Depressed Labor Market, As Explained by Participants." Mimeo, February 1993.

Bils, M. J. "Real Wages over the Business Cycle: Evidence from Panel Data." Journal of Political Economy, 93, 1985.

----, and K. J. McLaughlin. "Inter-Industry Mobility and the Cyclical Upgrading of Labor." NBER Working Paper No. 4130, August 1992.

Blank, R. M. "Why Are Wages Cyclical in the 1970s?" Journal of Labor Economics, 8, January 1990.

Blanchard, O.J. and S. Fischer. Lectures on Macroeconomics. Cambridge: MIT Press, 1989.

Brown, J.N. and Light, A. "Interpreting Panel Data on Job Tenure." Journal of Labor Economics, 10, 1992.

Chirinko, R.S. "The Real Wage Rate Over the Business Cycle.” Review of Economics and Statistics, 67, 1980.

Coleman, T.S. "A Note on the Measurement of Aggregate Effects in Panel Data." Unpublished manuscript, November 1986.

Doeringer, P.B. and Piore, M.J. Internal Labor Markets and Manpower Analysis. Lexington: D.C. Heath, 1971.

Ghosal, V. and Loungani, P. "Evidence of Nominal Wage Rigidity from a Panel of U.S. Manufacturing Industries.” Mimeo. February 1993.

Gray, J.A. and Spencer. D. "Price Prediction Errors and Real Economic Activity." Economic Inquiry,28, 1990.

Hall, R.E. "The Process of Inflation in the Labor Market." Brookings Papers on Economic Activity, 4, 1974. 
Keane, M., Moffit, R., and D. Runkle. "Real Wages over the Business Cycle: Estimating the Impact of Heterogeneity with Micro Data. " Journal of Political Economy, 96, 1988.

Reder, M. W. "The Theory of Occupational Wage Differentials." American Economic Review, 45.1955.

Shin, D. "Cyclicality of Real Wages Among Young Men.” Economic Letters, 46, 1994.

Solon, G. and R. Barsky. "Real Wages Over the Business Cycle." NBER Working Paper No. 2888. March 1989.

---, Barsky, B., and J. Parker. "Measuring the Cyclicality of Real Wages: How Important is Composition Bias?" Quarterly Journal of Economics, 109, 1994.

---, G., W. Whatley and A. H. Stevens, "Real Wage Cyclicality Between the World Wars: Evidence from the Ford and Byers Companies." Mimeo, October 1993.

Stockman, A.C. "Aggregation bias and the cyclical behavior of real wages." Unpublished manuscript, 1983.

Sumner, S. and S. Silver. "Real Wages. Employment. and the Phillips Curve," Journal of Political Economy. 97, 1989. 


\section{Appendix A}

Table A -- Cyclicality of Firm Employment, Various Worker Categories

\begin{tabular}{||l||c|l|l|l|l||}
\hline \hline $\begin{array}{l}\text { Independent } \\
\text { Variable }\end{array}$ & Total & Stayers & Movers & Hires & Leavers \\
\hline \hline Firm 1 & -0.019 & -0.921 & 5.530 & 5.492 & -0.005 \\
$\Delta \operatorname{Ln}($ Emp) & $(0.171)$ & $(0.565)$ & $(1.965)$ & $(1.979)$ & $(1.543)$ \\
(std. error) & 0.966 & 0.761 & -4.028 & 4.234 & -1.759 \\
Inflation & $(0.324)$ & $(0.908)$ & $(3.514)$ & $(3.736)$ & $(3.046)$ \\
& & & & & \\
\hline Firm 2 & -1.868 & -1.166 & 0.905 & -2.363 & -6.597 \\
$\Delta$ Ln(Emp) & $(0.734)$ & $(1.479)$ & $(1.818)$ & $(6.388)$ & $(3.005)$ \\
$($ std. error) & 0.662 & 0.087 & 1.344 & 3.158 & -1.051 \\
Inflation & $(0.367)$ & $(0.802)$ & $(0.985)$ & $(3.463)$ & $(1.627)$ \\
\end{tabular}


Wage Averages for Stayers, Leavers, and Hires, by Grade

GRADE 4
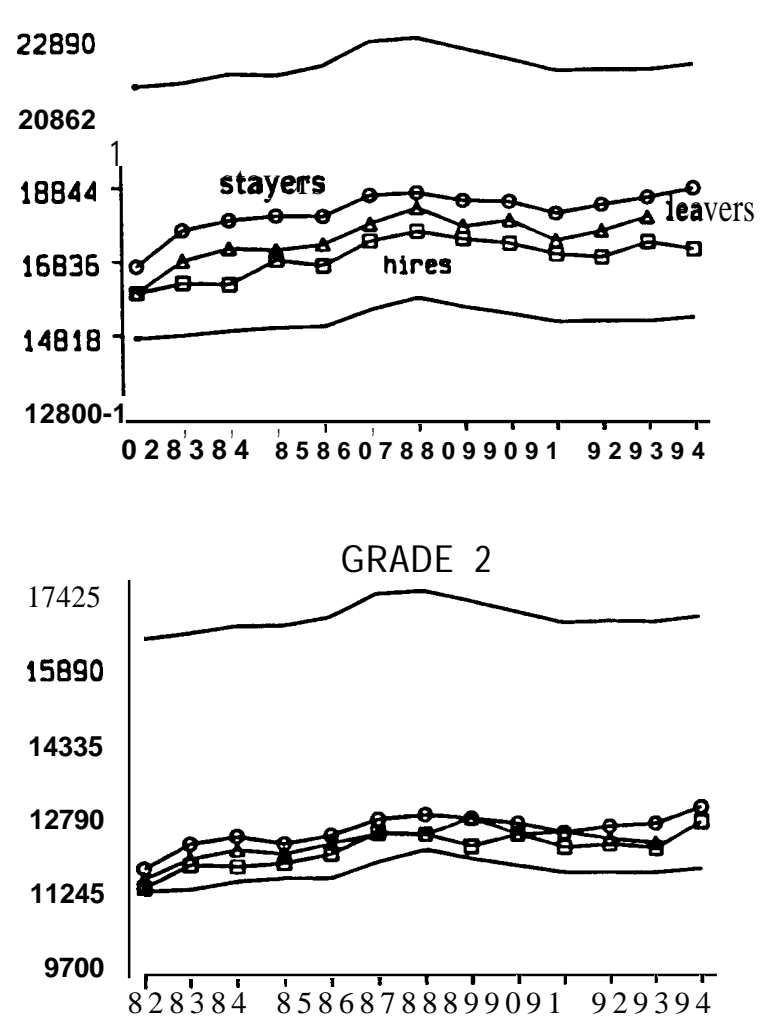

GRADE 3

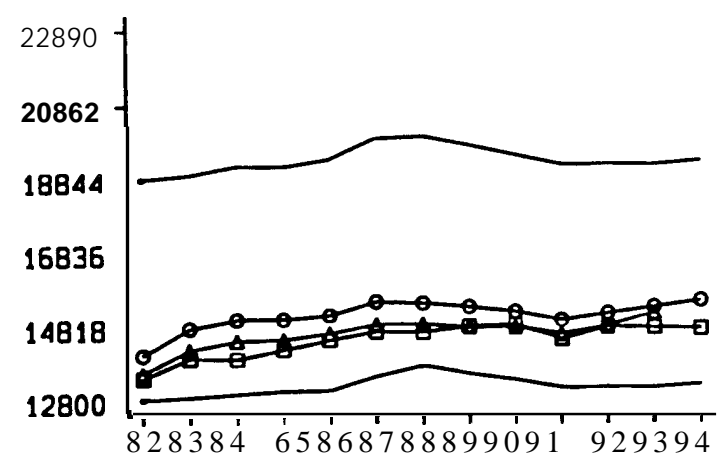

GRADE 1

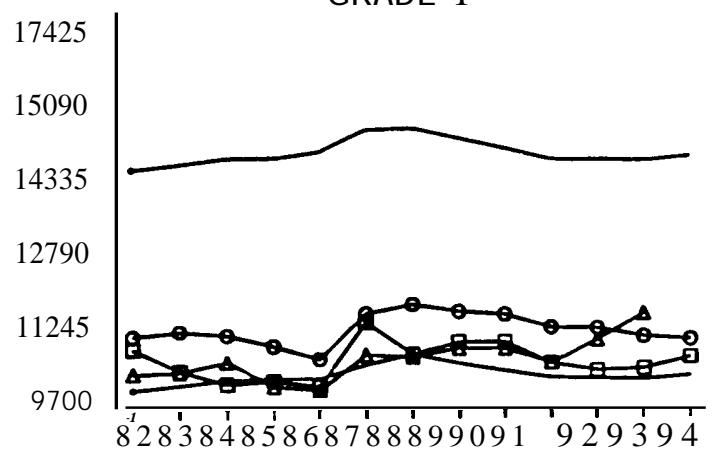



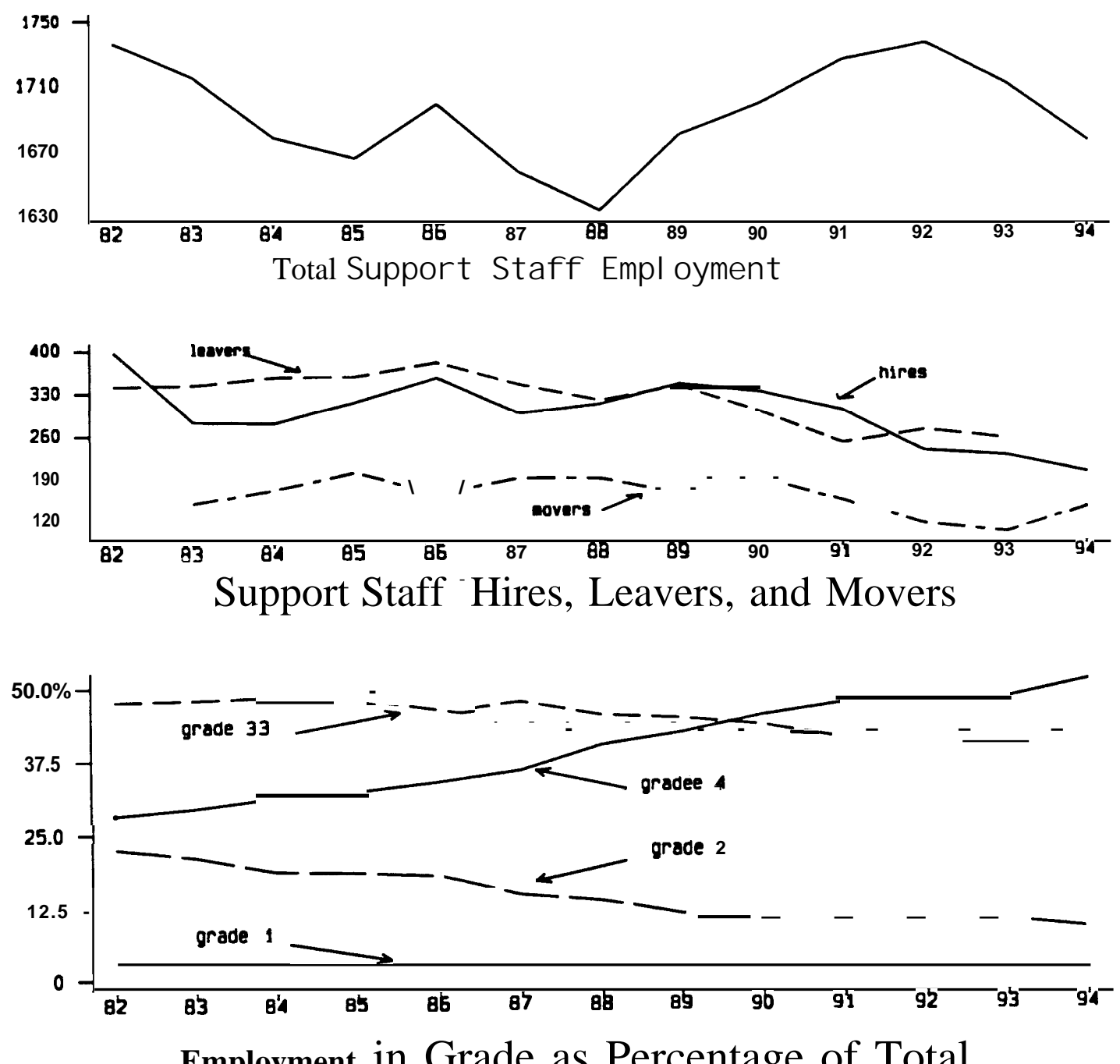

Employment in Grade as Percentage of Total 
Graph 3

Firm 1

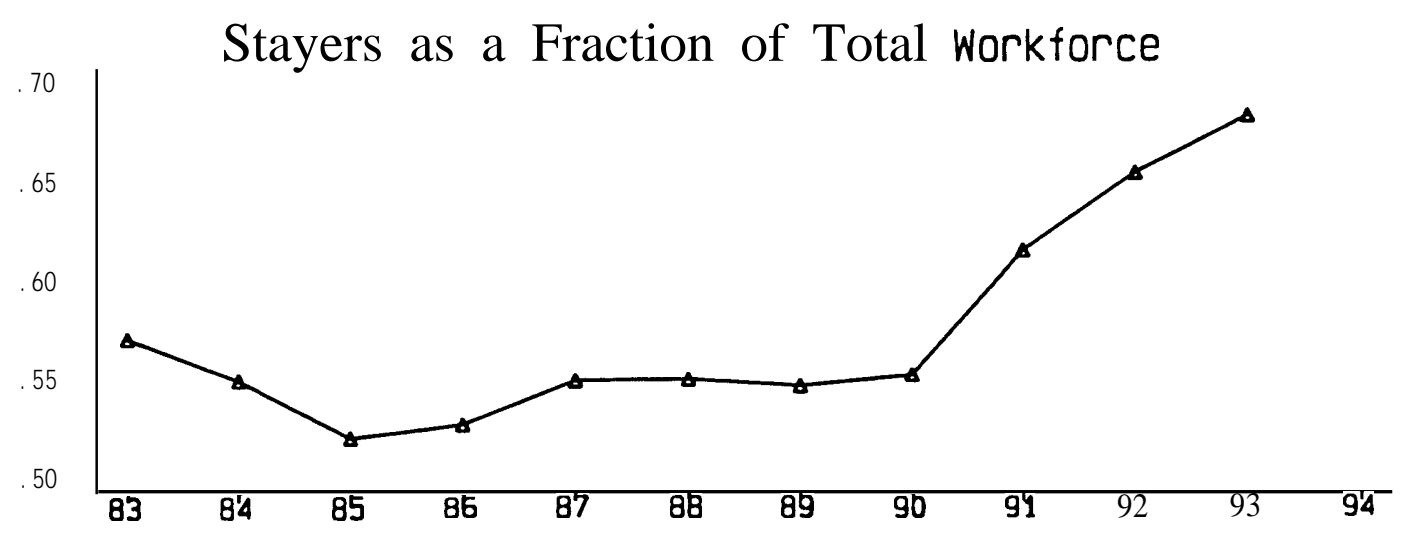

Level and Title Switchers as a Fraction of Total Workforce

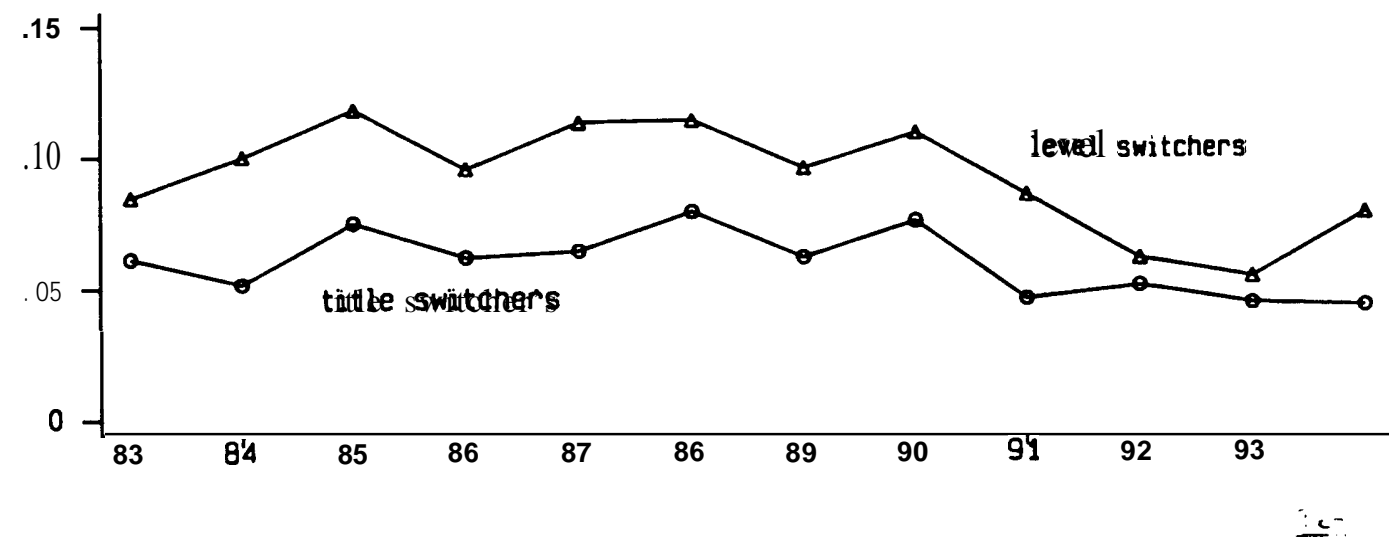




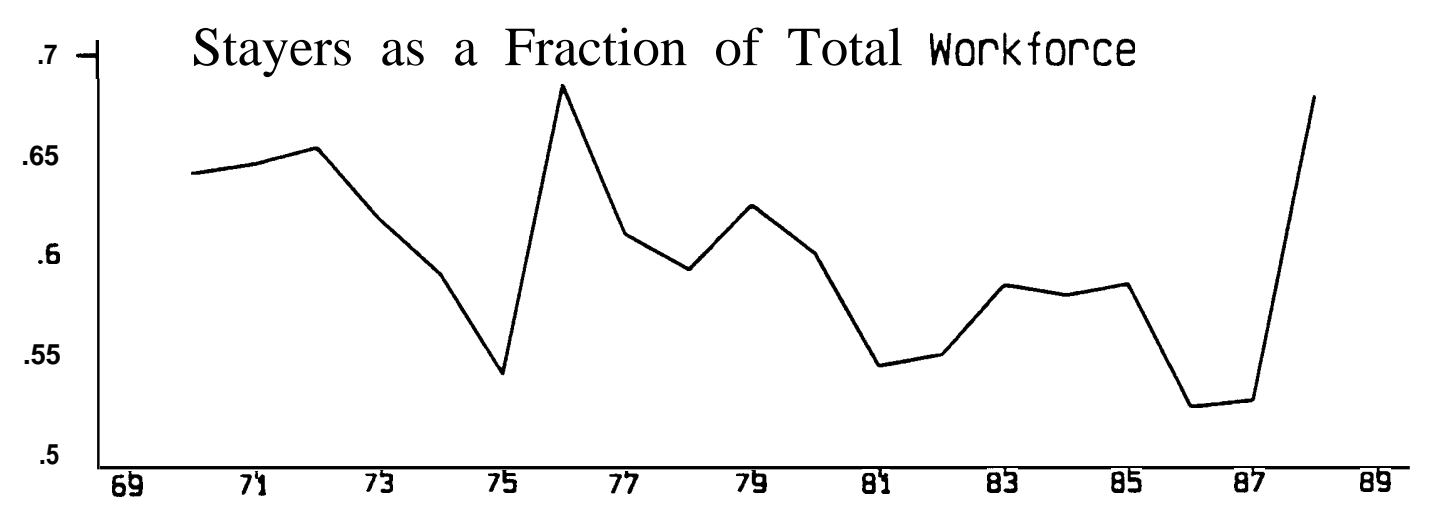

J ob Switchers and Leavers as a Fraction of Total Workforce

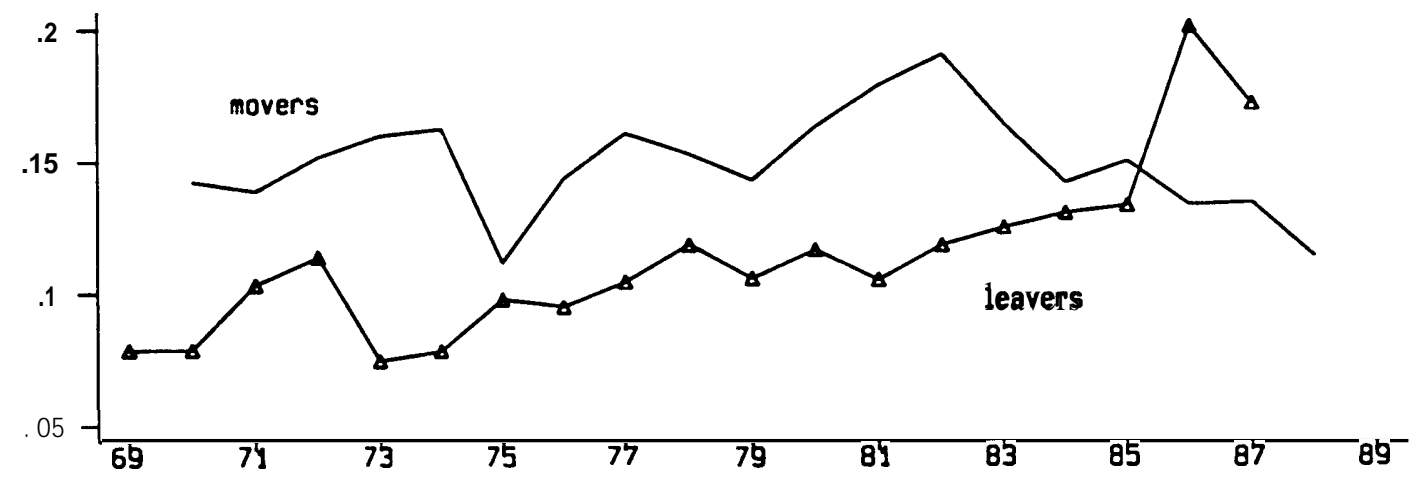


Graph 5

Firm 2

Employment in Grade as a Fraction of Total
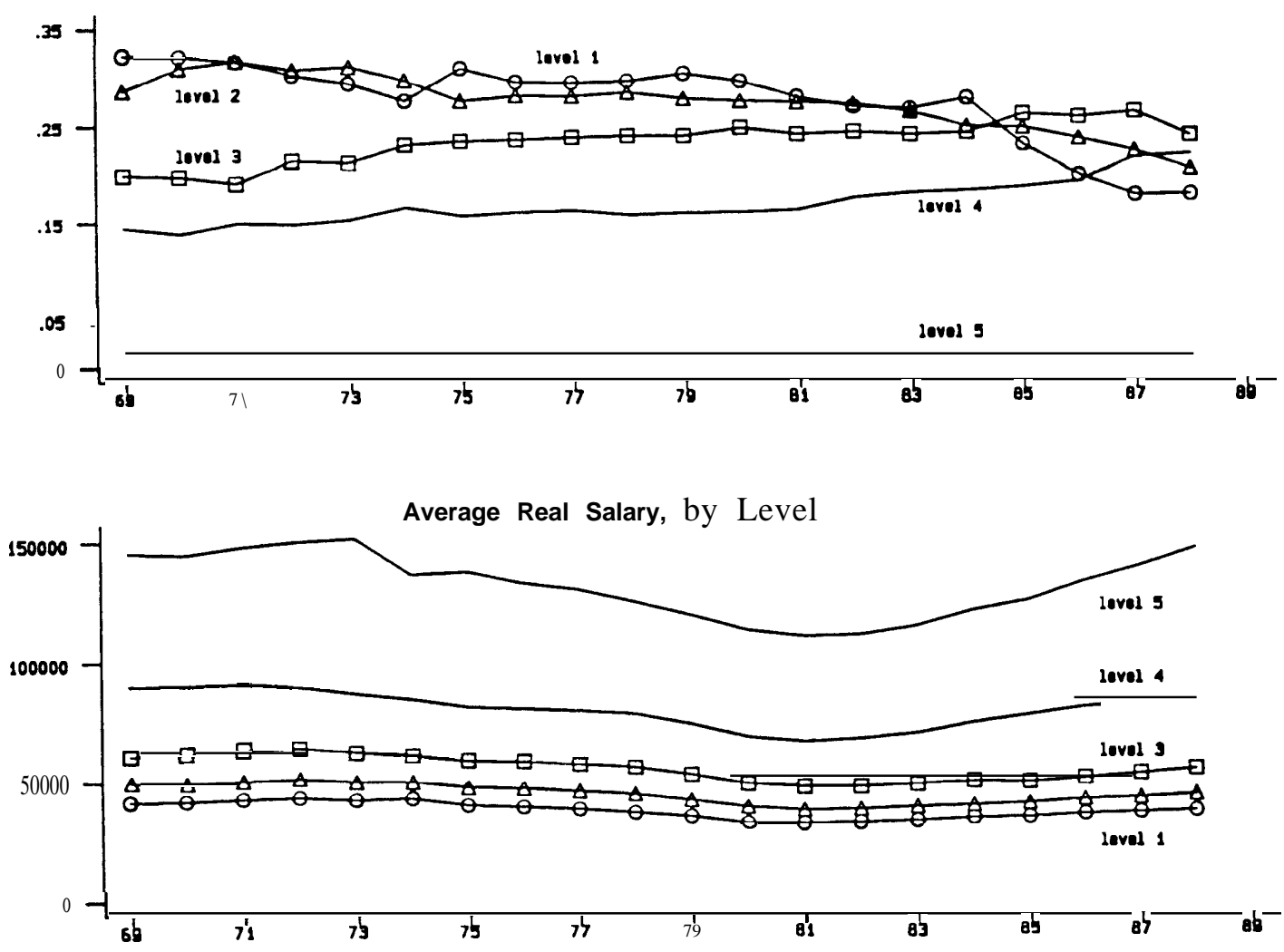
Graph 6

Firm 1

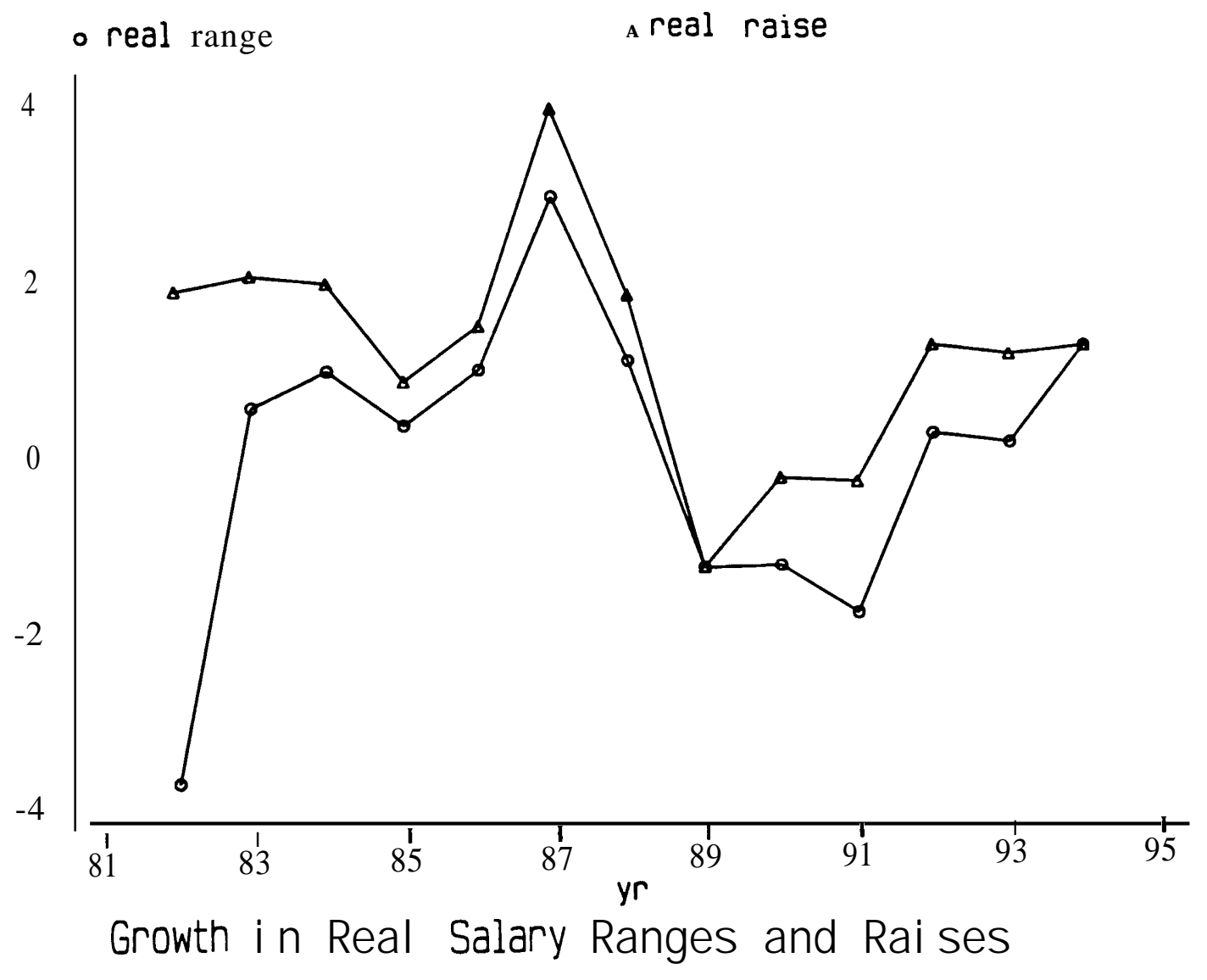


Nominal Sal ary Distribution and Grade Ranges, 1988

5th, 25th, 50th, 75th, 95th Percentile of Salaries in E a c h Grade

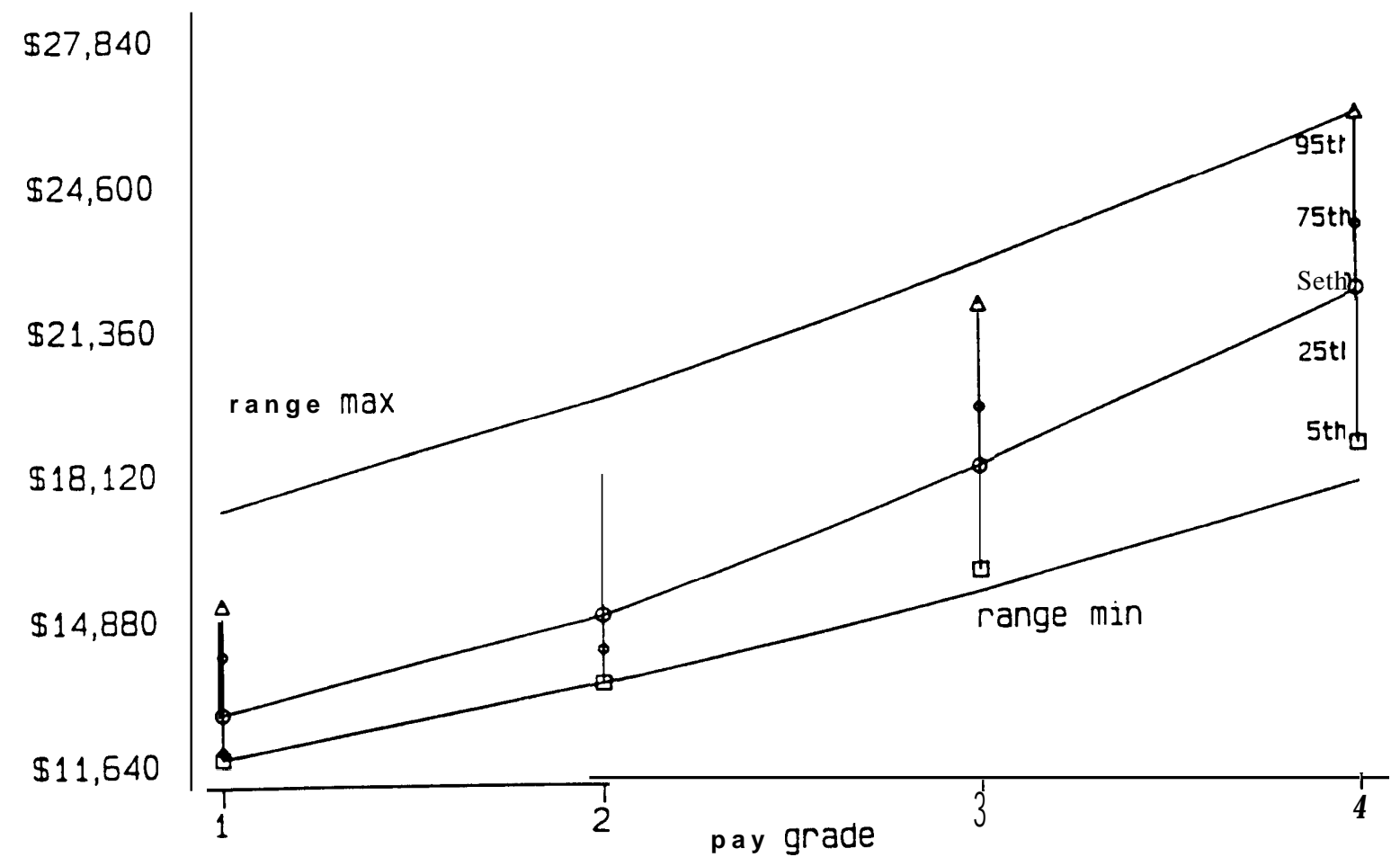




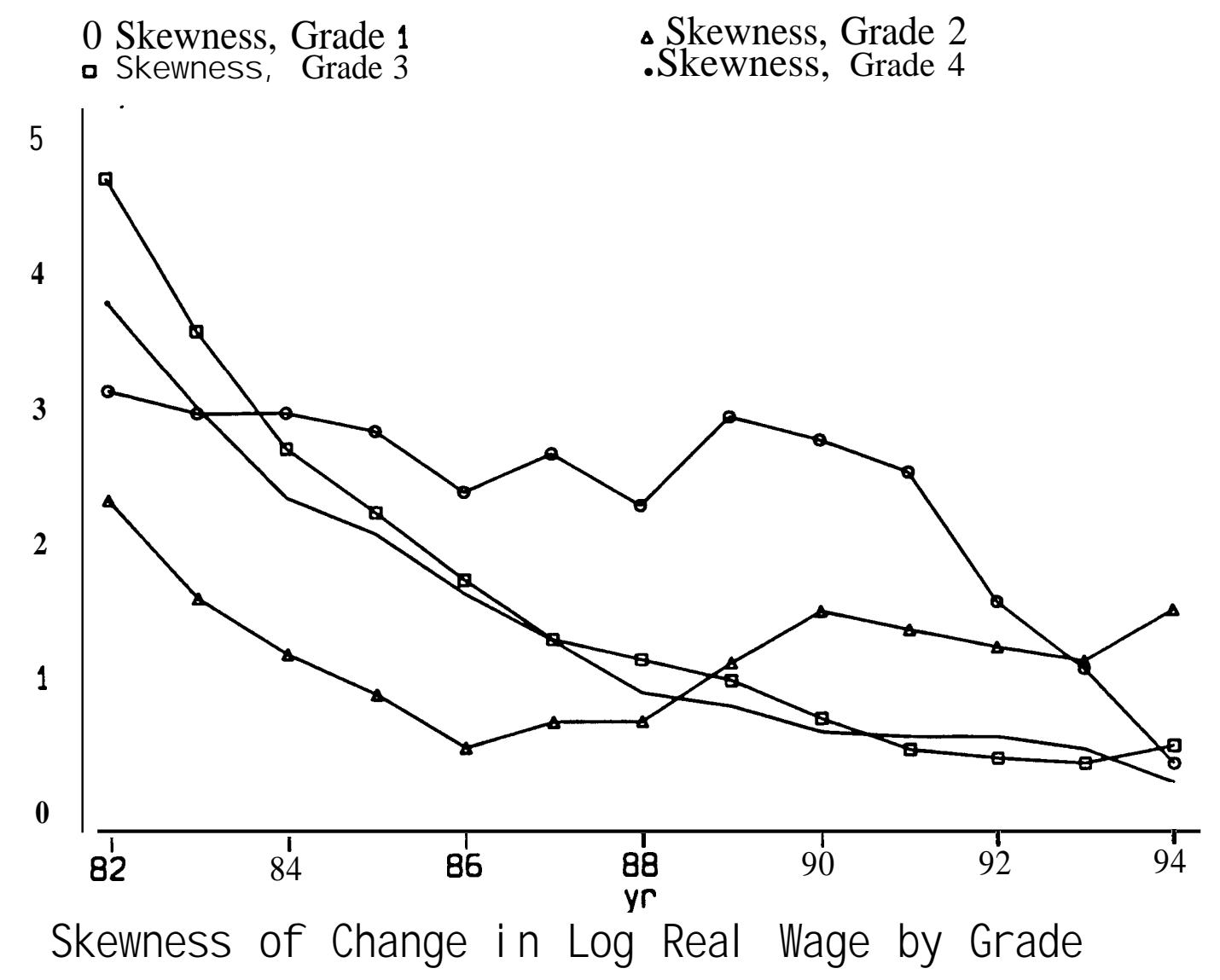

